Reprinted with permission from: Proceedings: Leafy Spurge Symposium. Bismarck, North Dakota. June 26-27, 1979. pp. 35-52.

Sponsored by: North Dakota State University Cooperative Extension Service, North Dakota State University Agricultural Experiment Station, Agricultural Research-USDASEA, and United States Forest Service.

\title{
Cropping cultivation, and herbicides to eliminate leafy spurge and prevent reinfestation
}

\author{
LYLE A. DERSCHEID \\ Extension Agronomist and Professor of Plant Science, South Dakota Cooperative Extension Service. Formerly leader \\ of weed research project with South Dakota Agricultural Experiment Station 1946-1964.
}

Since the Proceedings of this Symposium are to be used as a leafy spurge control reference manual, the writer has included most of the information from two of his papers published in Weeds in 1960 and 1963, including a "Review of Literature" and "Bibliography" that may be useful to some of the readers.

Though the control methods that include intensive cultivation and annual crops may not be useable in grassland or wooded areas, the treatments involving perennial grasses may be useful. The methods discussed here, though developed two decades ago, are believed to be the best methods available for use in eliminating leafy spurge on cultivated land.

The following exerpts were taken from the paper listed as Number 15 under "Literature Cited".

Leafy spurge is a perennial weed that is found in almost every state north of the fortieth parallel and in the southern portions of most Canadian provinces. Heaviest infestations are found in Minnesota, the Dakotas and the Prairie Provinces.

Hanson and. Rudd (10) conducted extensive life history studies in North Dakota. They adopted the name Euphorbia virgata Waldst. \& Kit.; however, Stevens (12), also of North Dakota, used the name Euphorbia esula $\mathrm{L}$. The two names apparently were used for the same species. Hanson and Rudd (10) described it as a long-lived perennial herb, somewhat woody at the base, containing milk sap. It grows to a height of 14 to 40 inches and propagates by means of seeds and roots. Near Fargo, average plant height was 1/2 inch April 5, 1 1/5 inches April 19, 3 1/2 inches April 23, and 12 1/2 inches April 30. Flowers began to appear by the end of May. This rapid early growth gives the weed a great advantage over most crop plants.

"The most formidable part of the plant is the root...It is well developed. The large tap root begins to branch into a number of large, woody, brown-colored branches near the surface. The fine roots are numerous, especially near the surface and when suitable con- 
ditions occur in deeper soil. The maximum depth at which roots were found was at the water table at 8 feet. The maximum lateral spread was $31 / 2$ feet' (10). This description is very similar to the description of the root system of field bindweed (Convolvulus arvensis L.) given by Frazier (9). The main differences are that the leafy spurge root is more woody and less extensive in a clay soil than the root of a non-competing bindweed plant growing in a sandy loam soil. Pieces of leafy spurge roots as small as one-half inch long and one-eighth inch in diameter produced new shoots which grew rapidly (10).

The fruit is a 3-chambered capsule, explosively dehiscent, usually along the line of union of the carpels. Normally each carpel contains one seed. Nearly 50 percent of the fruits produce one mature seed, about 35 percent produce two, and 15 to 20 percent produce three. In the vacinity of Fargo, the fruits begin to ripen about July 10 and continue until September. Upon maturity the seeds are forcibly discharged up to a distance of at least 13 feet. In one test, they were uniformly distributed in an area extending from 1 to 13 feet from the parent plant (10).

Thousands of acres of South Dakota farmland are infested with leafy spurge. Since it is not economically possible to put the land out of production while the leafy spurge is being eliminated, the objectives of the study reported in this paper were to determine methods of eliminating the weed in large areas while crops adapted to South Dakota were being produced and to determine methods of eliminating small infestations with chemicals.

Very few data could be found in the literature to serve as a guide when planning the study. However, life history studies $(9,10)$, root reserve studies $(1,3,4,8)$, and methods of control studies ${ }^{1}(2,3,11,13)$ indicated that leafy spurge and field bindweed were similar in growth habits, and that some of the methods for eliminating field bindweed were effective for the control of leafy spurge.

When bindweed roots were cut 4 inches below the soil surface every 14 days, root reserves were reduced (8). A duckfoot cultivator proved to be an effective implement for cutting the shoots in the field $(11,13)$, and it was desirable to start operations early in the spring to take advantage of the decline in root reserves during the winter (4). The 14-day interval between cultivations sometimes could be lengthened to 3 weeks, especially during the late summer when plants became dormant (13). In other work, the best interval was 2 weeks for bindweed, 3 weeks for Russian knapweed Centaurea repens L., and 4 weeks for hoary cress (Cardaria draba (1.) Desv.) and dogbane (Apocynum cannabinum L.) (14). Complete elimination of these weeds was obtained in 1 to 2.5 years. To secure similar results with leafy spurge, it was necessary to cultivate semiweekly for 2 years when a spring-tooth harrow was used (2).

Early spring cultivation, followed by a close-seeded crop of forage sorghum, soybeans, or sudangrass harvested for forage, followed by fall cultivation, reduced bindweed stands and resulted in complete elimination when continued for 3 years $(3,11,13)$. Simi-

${ }^{1}$ Stahler, L. M., and Derscheid, Lyle A. Unpublished data from South Dakota Bindweed Research Farm, 1946-1950. These data support most of the statements made in this section on control of bindweed.

Page 2 of 14 
lar results were obtained with leafy spurge (2). Buckwheat was an equally effective crop on quackgrass.

Alfalfa or alfalfa-perennial grass mixtures were sufficiently competitive to reduce stands of bindweed that had been weakened by a short season of intensive cultivation ( 3 , 11). Perennial grasses prevented bindweed from spreading (13), but were less effective for reducing stands than alfalfa or alfalfa-grass mixtures (11) However, bindweed stands were reduced by spraying bromegrass with 2,4-D. Alfalfa was less effective for controlling leafy spurge (2).

Two or three crops of winter wheat or rye alternated with intensive cultivation between crops gave elimination of bindweed $(3,11,13)$, and spring sown grains were equally effective. However, spring sown grains or corn could not compete effectively with leafy spurge (2). Spraying spring sown grains with 2,4-D could be used to replace cultivation between crops for the elimination of bindweed, but elimination was obtained in less time when spraying and cultivating were both utilized.

Numerous experiments conducted by the authors indicated that 2,4-D was equal to or superior to 2,4,5-T, MCPA, and several related chemicals for control of leafy spurge. Results indicated that the ester forms of 2,4-D were more readily absorbed than the amine forms. Leafy spurge reacted to less than one-fourth pound acid equivalent per acre. However, the stand was not materially reduced by 2 or 3 treatments in 1 year with much higher rates. Although the weed was easily affected by the chemical, it was quite resistant. It appeared that the weed could be weakened with 2,4-D so that a crop could compete more effectively with it or that cultivation could kill it more readily.

These results indicated that the objectives of this study could be attained with the proper combination of crops, cultivation, and chemicals. If the area were cultivated when not occupied by a crop and if the weed were selectively sprayed in a crop tolerant to the chemical, it appeared that several combinations might eliminate the weed in a few years.

\section{Experimental procedure and results}

Screening trials in which rates, dates, formulations, and chemicals were compared had been conducted during 1948-50. It became apparent that the chemicals available were not practical for elimination of large infestations of leafy spurge. Consequently 30 acres of land heavily infested with leafy spurge were leased during 1950 to study methods of eliminating this weed. The land was a part of the Pir Nilsson estate located 18 miles northeast of Clear Lake in Deuel County, South Dakota, where annual rainfall is normally about 22 inches. The soil is a Forman loam.

\section{Annual crops, cultivation, and 2,4-D}

A 3-year experiment involving the use of annual crops (winter rye, oats, sudangrass, and buckwheat), intensive cultivation, and 2,4-D was initiated during the fall of 1950. Weed counts were made on 4 one-square-yard areas of each plot during the middle of May each year. The final counts were made in May, 1954. Identical 3-year experiments 
were initiated during the falls of 1951 and 1952, and they were completed during May, 1955 and 1956. Each experiment included the same 33 treatment combinations. Each treatment was repeated once in a randomized block design.

\section{Perennial crops, cultivation, and 2,4-D}

Three experiments involving the use of perennial forage crops, cultivation, and 2,4-D were conducted. They were initiated in August, 1950, 1951, and 1952, and were completed during May, 1954, 1955, and 1956. Each experiment included the same 44 treatments. Each treatment was repeated once in a randomized block design. Weed counts were made on 4 square-yard areas of each plot in mid May each year.

\section{Discussion}

Leafy spurge apparently is more difficult to eliminate than field bindweed. Although intensive cultivation appears to be equally effective on both species, the competitive crops and 2,4-D appear to be less effective on spurge.

In this study, intensive cultivation eliminated over 90 percent of the spurge in 1 year and 100 percent in less than 2 years, regardless of whether the operations were performed at 2- or 3-week intervals. Similar results have been obtained by cultivating spurge with a duckfoot cultivator every 2 to 3 weeks (6) or with a spring-tooth harrow twice each week (2). Spurge appears to be similar to bindweed as the latter was completely eliminated in 2 years or less 3 when duckfoot cultivated at 3-week intervals for the entire season $(11,13)$.

The "fallow-rye" method, which has been successfully used for the elimination of bindweed $(3,11,13)$, was less effective for killing spurge. The stand reduction was 10 , 22, and 52 percent at the end of the first, second, and third years, respectively.

Close-drilled crops of sudangrass and buckwheat appeared to be more strongly competitive than other crops used in this study. When three cultivations were performed before seeding and the stubble was plowed after harvest, these crops appeared to have the ability to reduce leafy spurge stands about 50 percent in 1 year and 80 percent in 2 years. Complete elimination of spurge in 2 years has been accomplished when a crop of closedrilled forage sorghum or soybeans was handled in a similar manner (2). However, the results in this study are similar to those obtained with $\operatorname{bindweed~}^{2}(3,11,13)$ when forage sorghum or soybeans was used as the competitive crop.

Previous work (2) indicates that the seeding of a leafy spurge infested area to a spring-seeded grain is a useless procedure. Similar results were obtained in this study. Spurge starts so early in the spring that it gets ahead of spring-seeded crops. However, an application of $1 / 2 \mathrm{lb} / \mathrm{A}$ of 2,4-D ester checks weed growth, making it possible for the grain to get ahead and hold the weeds in check. The results indicate that a reduced stand of leafy spurge can be held in check, but not further reduced during a year that a small grain crop is raised if 2,4-D application is made. This leads to the possibility of using

${ }^{2}$ Stahler, L. M., and Derscheid, Lyle A. Loc. cit.2

Page 4 of 14 
some system that will reduce the stand on alternate years with small grain that is sprayed. Alternate years of intensive cultivation and small grain sprayed with $2,4-\mathrm{D}$ is an effective method (6).

Although alfalfa was a good competitive crop for controlling bindweed $(3,11)$, it did not compete strongly with spurge in this study or in other experiments (2). Leafy spurge emerges at or before the time that alfalfa commences spring growth, and the spurge produces a rank growth which stays ahead of the alfalfa. Bindweed, on the other hand, emerges after alfalfa develops, and its prostrate form of growth allows the alfalfa to overshadow it.

Bromegrass was effective in reducing leafy spurge stands when aided by cultivation or application of 2,4-D. A short season of intensive cultivation prior to a fall-seeded crop eliminated 95 percent of the spurge. Bromegrass was capable of holding the weed in check, without the aid of 2,4-D. However, the stand was not further reduced even when 2,4-D was used.

When the cultivation was omitted, bromegrass that was sprayed with 2,4-D slowly reduced the stand of leafy spurge. The date of treatment appeared to be unimportant although fall treatments were least effective the first year. Two treatments a year did not appear to be superior to 1 treatment.

\section{Conclusions}

1. Leafy spurge stands can be materially reduced by use of the proper combination of competitive crop, cultivation, and 2,4-D.

2. Leafy spurge reacts to small amounts of 2,4-D but is not killed by much larger amounts. Ester forms cause much greater reaction than amine forms.

3. Leafy spurge can be eliminated with less than 2 years of intensive cultivation. Operations need not be performed oftener than every 3 weeks if a duckfoot cultivator is operated at a depth of 4 inches.

4. Spring-seeded small grains do not compete favorably with leafy spurge. However, grain sprayed with 2,4-D prevents spurge stands from becoming denser.

5. Sudangrass and buckwheat, where adapted, materially reduce the stand of leafy spurge when the seeding is preceded by three cultivations and harvest is followed by plowing.

6. Alfalfa does not compete favorably with spurge unless a heavier than normal stand of alfalfa is obtained.

7. Bromegrass sprayed with 2,4-D slowly reduces the stand of leafy spurge. It is more effective when fall seeding is preceded by a short season of intensive cultivation.

8. Several soil sterilants can be used to eliminate small patches of leafy spurge.

9. Amitrol and 2.3,6-TBA show great promise for use in eliminating large infestations of leafy spurge. 
The following statements are taken from the paper listed as Number 16 in the "Literature Cited" section.

Although the crops used in 1950-1956 are adapted to South Dakota, they were not used in profitable crop rotations. Consequently, a second series of studies was initiated to determine methods of eliminating large areas of leafy spurge while crop rotations adapted to South Dakota were being followed and to learn how to prevent reinfestation. During the course of this study rainfall was about 28 inches in 1956, 27 inches in 1957, 19 inches in 1958, 20 inches in 1959 and 25 inches in 1960. During April to August inc. the rainfall was 22 inches in 1956, 15.5 inches in 1957, 12 inches in 1958, 12 inches in 1959 and 20 inches in 1960 .

\section{Experimental procedure and results}

The 30-acre Research Farm used for the previous studies was also used for the experiments reported in this paper. Three types of experiments were conducted: (1) 4-year trials in which information gained in the previous studies was used to develop good cropping sequences for eliminating leafy spurge, (2) 2- or 3-year trials in which non-selective herbicides were applied before planting corn and after harvesting small grain to develop methods of eliminating the weed, and (3) 4-year experiments designed to learn how common crop rotations should be managed to prevent reinfestation of land on which the weed has been eliminated.

\section{Crops, cultivation and 2,4-D for elimination}

One 4-year experiment was initiated in 1956 in which 32 treatments were applied in triplicate on plots 1 rod X 5 rods in size. The second 4-year experiment was initiated during 1957. The same treatments were applied in quadruplicate. The number of leafy spurge shoots were counted on four permanent 1-square-yard areas of each plot during mid-May before initiating the experiment. Counts were made on the same areas in midMay of each succeeding year to determine the effect of each year's treatment. The first experiment was finished in May 1960 and the second 1 year later.

Rotations used were: (1) cultivation-alfalfa-alfalfa-corn, (2) cultivation-alfalfa-wheatcorn, (3) cultivation-bromegrass-bromegrass-corn, (4) cultivation-bromegrass-wheatcorn, (5) oats-bromegrass-bromegrass-corn, (6) oats-bromegrass-wheat-corn, (7) oatsoats-sweet clover-corn, (8) oats-oats-sweet clover and fallow-corn, (9) sudangrass-oatssweet clover and fallow-corn, (10) sudangrass-oats-wheat-corn, and (11) sudangrass-ryewheat-corn. They were modified with the addition of 2,4-D, and special cultivation to form 32 treatments in each experiment.

All cultivation and fallow operations were performed with a 7-foot duckfoot cultivator equipped with nine 12-inch sweeps operated at a depth of about 4 inches. The butoxyethanol ester of 2,4-D was applied in a volume of $12 \mathrm{gal} / \mathrm{A}$ for all 2,4-D applications. The treatments and data are given in Table 1.

Editor's Note: Tables referred to are not included but can be found in the original references. First year. Corn had been grown on the area during the previous year to allow the leafy spurge reinfestation to regain vigor after the previous studies had been terminated. 
Plots receiving treatments 1 to 15 were plowed during mid May and cultivated at 2week intervals ( 6 cultivations) between early June and mid-August. Ranger alfalfa at 8 lb/A or Homesteader bromegrass at $12 \mathrm{lb} / \mathrm{A}$ was seeded with oats as a companion crop during mid-August in these treatments. The stand of leafy spurge was reduced 82 percent for the 105 plots in the two experiments.

Plots receiving treatments 16 to 22 were tandem disked twice and drilled to oats at 1 $1 / 2 \mathrm{bu} / \mathrm{A}$ and Homesteader bromegrass at $12 \mathrm{lb} / \mathrm{A}$ during mid-April. All plots were sprayed with $1 / 3 \mathrm{lb} / \mathrm{A}$ of 2,4-D during early June, when the oats were in the 5-leaf stage, and plowed during late August. The stand of leafy spurge increased 62 percent on the 49 plots treated in this manner.

In treatments 23, 24 and 25, oats were seeded at $21 / 2 \mathrm{bu} / \mathrm{A}$. Treatments 24 and 25 included spraying with $1 / 3 \mathrm{lb} / \mathrm{A}$ of 2,4-D when grain was in the 5-leaf stage. All three treatments included post-harvest plowing in late July, a cultivation in late August and two cultivations in September. Treatment 23 allowed the weed population to increase 19 percent on 7 plots, while treatments 24 and 25 reduced the stand 68 percent on 14 plots.

Plots receiving treatments 26 to 32 were plowed during mid May and cultivated three times before Piper sudangrass was seeded with a grain drill at $25 \mathrm{lb} / \mathrm{A}$ during late June. Hay was harvested during early September and all plots were plowed immediately. Treatments 26 to 29 reduced the stand 79 percent on the 28 plots. Pierre rye was seeded at $11 / 2 \mathrm{bu} / \mathrm{A}$ on treatments 30 to 32 immediately after plowing. This procedure reduced the stand 90 percent on the 21 plots.

Second year. The stand of alfalfa was very poor in treatments 1 to 5 . Alfalfa was reseeded top-dressed with $100 \mathrm{lb} / \mathrm{A}$ of 0-46-0 fertilizer in mid-May, and cut for hay during mid-August. Treatments 2 to 5 included plowing early in September. This sequence had little effect on the stand of leafy spurge.

The bromegrass in treatments 6 to 15 was top-dressed with $120 \mathrm{lb} / \mathrm{A}$ of 33-0-0 fertilizer in mid-May and a hay crop was harvested during mid-June. Treatments 6 and 9 reduced the stand slightly. In treatments 7,8 and 10 to 15 , bromegrass was sprayed with 2,4-D at $1 \mathrm{lb} / \mathrm{A}$ in early June. In treatments 8 and 12 to 15 , grass was sprayed with an additional $1 \mathrm{lb} / \mathrm{A}$ of 2,4-D in mid August. All (7, 8 and 10 to 15) were plowed in early September, reducing the stand an additional 12 to 13 percent, indicating that the August application of 2,4-D in treatments 8 and 10 to 15 was not effective in reducing the leafy spurge stand.

Treatments 17 to 19 included one application of 2,4-D on bromegrass, while treatments 16 and 20 to 22 included two applications. All except treatment 16 included fall plowing. The stand of leafy spurge was reduced 51 percent at the end of 2 years on the 21 plots receiving one spraying the second year, and 54 percent on the 28 plots receiving two sprayings the second year, indicating once again that the August spraying was not effective.

Treatments 23 and 26 utilized an oat crop at 1 1/2 bu/A underseeded with Madrid sweetclover at $8 \mathrm{lb} / \mathrm{A}$ and no spraying. Both allowed the stand of leafy spurge to increase. Treatment 24 included a crop of S.D. 270 corn, three cultivations and an application of $1 / 3 \mathrm{lb} / \mathrm{A}$ of 2,4-D between the first and second cultivations. By this method, leafy spurge

Page 7 of 14 
stands were reduced by about 15 percent. Treatment 25 included cultivation and sudangrass as in the first year of treatments 26 to 29. It increased elimination by 20 to 25 percent.

Treatments 27 to 29 included a seeding of Garry oats at $21 / 2 \mathrm{bu} / \mathrm{A}$ and an application of $1 / 3 \mathrm{lb} / \mathrm{A}$ of 2,4-D during early June when the grain was in the 5-leaf stage. In addition $1 \mathrm{lb} / \mathrm{A}$ of 2,4-D was applied during mid-August in treatment 28. The stubble in treatments 27 and 28 was plowed in mid September, but it was plowed during late July in treatment 29 and cultivated three times during August and September. Each treatment increased the percentage of elimination by almost 20 percent.

Treatments 30 to 32 were the same as treatments 27 to 29 except that rye was used as the crop instead of oats. Each increased the percentage of elimination during the second year. At the end of 2 years, the results from treatments 27 to 32 were very similar.

Third year. Treatments $1,6,7,8$ and 16 included a crop of alfalfa or bromegrass that received the same fertilizer treatments as the previous year. Hay was harvested in midJune and plots were plowed during September. Without a spraying the crops had little effect on the stand to improve materially on 94 or 95 percent elimination, but two applications of $1 \mathrm{lb} / \mathrm{A}$ of 2,4-D in treatment 16 improved on 51 percent elimination from the previous year by about 30 percent. Although treatment 16 allowed the stand to increase the first year, it was equal to treatments 2 and 6 at the end of the third year.

Treatments 23 and 26 included sweetclover that was plowed during late June, tandem disked in July and cultivated five times during late July, August and September. Both improved the results materially, over the first year. All other treatments included a crop of Selkirk wheat at $1 \mathrm{bu} / \mathrm{A}$. In treatments 2 and 9, the crop was harvested and the Stubble plowed in early September. The stand of leafy spurge was not affected.

Treatments 3, 10, 13, 17, 20, 27 and 30 included an application of 1/2 lb/A of 2,4-D during early June when the crop was in the 5-leaf stage, and a fall plowing during late August. The average of 81 percent elimination for these treatments at the end of 2 years was not changed. However, the average of 92 for treatments 3, 10, 13, 27 and 30 was maintained.

Wheat in treatments $4,11,14,18,21,28$ and 31 was sprayed with 2,4-D at 1/2 lb/A in early June and $1 \mathrm{lb} / \mathrm{A}$ after harvest and plowed in September. The average for these treatments was 80 percent at the end of 2 years and 87 percent at the end of 3 years. The average for treatments 4,11, 28 and 31 was 92 at the end of 2 years and 97 at the end of 3 years.

Treatments 5, 12, 15, 19, 22, 24, 25, 29 and 32 included 1/2 1b/A of 2,4-D in early June, plowing in late July and three cultivations in August and September. Again the average for these treatments, 80 percent elimination at the end of 2 years, was not materially changed the third year.

Fourth year. All treatments consisted of a crop of S.D. 270 corn that was cultivated three times. An application of $1 / 3 \mathrm{lb} / \mathrm{A}$ of 2,4-D between the first and second cultivations was included in treatments 3 to 5 and 10 to 32 . Treatments 1 to 9 eliminated 88 percent in 3 years and 85 percent in 4 years. Treatments 10 to 32 eliminated 77 percent of the weed 
in 3 years and 77 percent in 4 years. The results indicate that corn, with or without spraying, had little effect on the stand of the weed.

Crop yields. Average yields of unsprayed oats were $32 \mathrm{bu} / \mathrm{A}$ for the first year and 54 for the second year, while yields of oats sprayed with $1 / 3 \mathrm{lb} / \mathrm{A}$ of 2,4-D were 37 and 60 $\mathrm{bu} / \mathrm{A}$, respectively. Average wheat yields were $16 \mathrm{bu} / \mathrm{A}$ for unsprayed plots and 14.6 for those sprayed with $1 / 2 \mathrm{lb} / \mathrm{A}$ of 2,4-D. Unsprayed corn produced $31 \mathrm{bu} / \mathrm{A}$, while that sprayed with $1 / 3 \mathrm{lb} / \mathrm{A}$ of 2,4-D yielded $34 \mathrm{bu} / \mathrm{A}$. Fall-seeded bromegrass in treatments 6 to 15 yielded an average of $0.31 \mathrm{~T} / \mathrm{A}$ the second year, while spring-seeded bromegrass in treatments 16 to 22 produced $0.34 \mathrm{~T} / \mathrm{A}$.

Summary. Exactly half of the treatments eliminated 90 percent or more of the leafy spurge in 4 years. These included nine of the fifteen treatments that utilized a season of intensive cultivation before seeding a perennial crop the first year and six of the seven treatments that included cultivation and a crop of sudangrass the first year. The other treatment included cultivation and sudangrass the second year. Only two of the five treatments utilizing cultivation and alfalfa the first year eliminated over 90 percent of the spurge in 4 years. Third year operations were important. Alfalfa or wheat without postharvest operations were inferior to wheat that was sprayed in the grain and either sprayed or cultivated after harvest.

Seven of the ten operations that included cultivation and bromegrass the first year eliminated over 90 percent of the leafy spurge. The use of brome the second year and either brome or wheat the third year without 2,4-D application or the use of brome for 2 years with only one application each year proved to be ineffective in treatments 6,7 and 9. However, two 2,4-D applications a year in bromegrass for 2 years (treatment 8) increased the effectiveness. One or two applications in bromegrass the second year, a fall plowing and a wheat crop that was sprayed the third year also proved to be effective follow-up operations to the cultivation and bromegrass used the first year.

One year of cultivation and sudangrass (treatments 25 and 27 to 32) were such effective operations that spraying in small grain reduced stands still further the next year and similar operations maintained the percentage kill in subsequent years.

\section{Crops, cultivation, 2,4-D and non-selective herbicides}

In previous studies 4 to $6 \mathrm{lb} / \mathrm{A}$ of 2,3,6-trichlorobenzoic acid (2,3,6-TBA) applied before planting corn reduced leafy spurge stands 80 to 90 percent, while similar herbicidal applications in oats stubble reduced stands 75 to 85 percent. These combinations of treatments were incorporated into one 3 -year experiment and three 2 -year experiments. In two experiments corn was planted the first year and oats the second. The crop sequence was reversed in the other two. Treatments were applied in triplicate on plots 1 rod by 3 rods. Leafy spurge counts were made on four permanent 1-square-yard areas before initiating each experiment and during mid-May each subsequent year to determine density at the outset and the effect of each year's treatment.

In each test butoxyethanol ester of 2,4-D at $1 / 3 \mathrm{lb} / \mathrm{A}$ was applied to the crop. Liquid formulations of herbicides were applied in $12 \mathrm{gal} / \mathrm{A}$ of spray solution while wettable powders were applied in 20 gal/A. Dimethylamine salt of 2,3,6-TBA and 3-amino-1,2,4-

Page 9 of 14 
triazole (amitrole) were used in all four experiments, while the dimethylamine salt of polychlorobenzoic acids (PBA) was tested twice, 2-chloro-4,6-bis(ethylamino)-s-triazine (simazine) and the butyl ether ester of 2-(2,4,5-trichlorophenoxy) propionic acid (silvex) were tested once. Treatments and data for 2,3,6-TBA and amitrole are given in Table 2.

Oats and corn. Experiment 1 in Table 2 is one of two experiments in which oats was grown the first year. Treatments were not identical in the two trials, but results were similar for treatments common to both tests.

During the first year the oats was sprayed with 2,4-D when in the 5-leaf stage. In midAugust herbicides were applied to the stubble. Plowing was performed 10 days later on PBA- and 2,3,6-TBA-treated plots and 15 days later on amitrole-treated plots. PBA was unsatisfactory in the first test and omitted from the second. However, 2,3,6-TBA and amitrole reduced leafy spurge stands materially.

During the second year, 2,3,6-TBA and amitrole were applied in mid-May when leafy spurge was 6 to 10 inches tall. Ten days later all plots were duckfoot cultivated. S.D. 270 corn was planted immediately. It was cultivated three times during the season, and sprayed with 2,4-D one week after the first cultivation. The stand of leafy spurge became more dense on all plots in both experiments. There was no evidence of crop injury from most treatments even though two applications were made in a period of 9 months. Slight damage to the corn was noted on plots treated with $6 \mathrm{lb} / \mathrm{A}$ of 2,3,6-TBA in August plus 4 lb/A in May. Corn was damaged severely by a similar treatment in a test on Russian knapweed.

Corn and oats. Experiment 2 in Table 2 is one of two tests in which corn was planted the first year. In one test silvex at 5,10 or $15 \mathrm{lb} / \mathrm{A}$, simazine at 2,4 , or $8 \mathrm{lb} / \mathrm{A}, \mathrm{PBA}$ at 2 , 4,6 or $8 \mathrm{lb} / \mathrm{A}, 2,3,6-\mathrm{TBA}$ and amitrole at rates shown in Table 2 were applied in midMay. Ten days later the plots were plowed. Corn was planted, cultivated and sprayed with 2,4-D. PBA and simazine were ineffective. Silvex equalled 2,3,6-TBA and amitrole for weed control, but killed the corn. The rates of 2,3,6-TBA and amitrole were not all identical with those in Experiment 2, but results were similar for rates that were common to both trials. Both herbicides reduced the stands materially.

During the second year, oats was handled the same as described for Experiment 1. The stand of leafy spurge was not materially decreased in either trial. No crop damage was noted either year. Herbicide applications were 15 months apart and a 9-month period elapsed between the second application and the planting of the next crop.

One test was continued a third year. Third-year treatments were a repetition of first year treatments with the herbicides applied before planting corn. Both 2,3,6-TBA and amitrole held the leafy spurge in check but failed to reduce stands materially.

\section{Crops, cultivation and herbicides to prevent reinfestation}

Two 4-year experiments were initiated in 1956 and 1957 and terminated in May 1960 and 1961. Each was conducted in quadruplicate on areas where leafy spurge had been weakened by previous experiments and eliminated with intensive cultivation for one sea- 
son. No leafy spurge plants were found on four 1-square-yard areas of each 1-rod X 5-rod plot when the trials were initiated. The number of established shoots was determined on the same four 1-square-year areas each May to determine the effect of each year's treatment.

Five basic rotations, (1) oats-oats-wheat-corn, (2) oats-corn-wheat-corn, (3) oatsalfalfa-wheat-corn, (4) oats-sweet clover-wheat-corn and (5) oats-sweet clover and fallow-wheat-corn were each modified four times by the use of 2,4-D or 4-(2,4dichlorophenoxy) butyric acid [4-(2,4-DB)] 4-(2,4-DB) and special cultivation to form 20 treatments. All cultivation and fallow operations were performed with a duckfoot cultivator. The butoxyethanol ester of 2,4-D was used for most spraying, however, a triethanol amine of 2,4-D was used in the first year of several treatments. The treatments and data are presented in Table 3.

First year. Oats was seeded at $21 / 2 \mathrm{bu} / \mathrm{A}$ in treatments 1 to 8 . One-fourth $\mathrm{lb} / \mathrm{A}$ of 2,4-D amine, in treatments 2 to 4 , and 1/3 lb/A of 2,4-D ester, in treatments 6 to 8 , were applied when oats were in the 5-leaf stage. Treatments 3 and 7 included $1 \mathrm{lb} / \mathrm{A}$ of 2,4-D in grain stubble during mid-August. All included plowing early in September except 4 and 8 which included plowing during late July and two cultivations during August and September. Only two treatments allowed more than one leafy spurge plant per square yard to become established.

Treatments 9 to 20 included oats at $11 / 2 \mathrm{bu} / \mathrm{A}$ under-seeded with Ranger alfalfa or Madrid sweetclover. Three treatments in each rotation included an application of $1 / 4 \mathrm{lb} / \mathrm{A}$ of 2,4-D amine in the first test and $1 \mathrm{lb} / \mathrm{A}$ of $4-(2,4-\mathrm{DB})$ in the second. A poor stand of sweetclover was obtained in the first trial and only a fair stand in the second. The treatments without spraying allowed less than one leafy spurge plant per square yard to become established, while those with spraying allowed almost two plants. The legume stand was seriously injured by spraying in the first experiment.

Second year. Treatments 1 to 4 included Garry oats at 2 1/2 bu/A with an application of $1 / 3 \mathrm{lb} / \mathrm{A}$ of 2,4-D ester when the crop was in the 5-leaf stage for treatments 2 to 4 and a postharvest application of $1 \mathrm{lb} / \mathrm{A}$ of 2,4-D ester or postharvest cultivation in treatments 3 and 4 . Treatments 1 to 4 prevented leafy spurge from increasing and stands were reduced slightly by those that included an application of 2,4-D.

Corn was planted in treatments 5 to 8 . It was cultivated lengthwise twice and crosswise once during the season. One-third lb/A of 2,4-D ester was applied shortly after the first cultivation in treatments 6 to 8 . Leafy spurge stands appeared to have been reduced by treatments 5,6 , and 8 , indicating the 2,4-D application was not necessary for killing seedlings or 1-year-old plants.

In treatments 9 to 12 , the alfalfa appeared to have reduced the stand almost 50 percent. In treatments 13 to 20 , a crop of sudangrass in the first experiment, and a crop of sweetclover in the second experiment, appeared to be superior to the alfalfa. In the second experiment, sweetclover was harvested for seed in treatments 13 to 16 . The sweetclover in treatments 17 to 20 was plowed during late June, tandem disked once and cultivated three times during July, August and September.

Page 11 of 14 
Third year. All treatments included a crop of Selkirk wheat. In each of the five rotations one treatment $(1,5,9,13,17)$ did not include any $2,4-\mathrm{D}$ or late summer cultivation. One treatment $(2,6,10,14,18)$ in each rotation included an application of $1 / 2 \mathrm{lb} / \mathrm{A}$ of 2,4-D ester when the wheat was in the 5-leaf stage. The remaining treatments included an identical application of 2,4-D and a postharvest application of $1 \mathrm{lb} / \mathrm{A}$ of 2,4-D ester (3, 7, $11,15,19)$ or a plowing in early August and two cultivations in August and September $(4,8,12,16,20)$. All other treatments included plowing during early September.

The stand of leafy spurge increased from 0.5 to 1.1 plants per square yard for treatments $1,5,9,13$ and 17 and from 0.3 to 0.5 for treatments $3,7,11,15$ and 19 but remained constant on plots receiving other treatments. These results indicate that the optimum treatment included a spraying of 2,4-D in the grain, without a fall operation.

Fourth year. All treatments included a crop of S.D. 270 corn that was cultivated three times. Three treatments in each rotation included an application of 1/3 lb/A of 2,4-D ester shortly after the first cultivation. The 120 plots receiving this treatment contained an average of 0.3 plants per square yard after 3 years, and 0.4 after 4 years.

The fourth treatment in each rotation did not include the application of 2,4-D. These 40 plots contained an average of 1.1 plants per square yard at the end of the third year, and 2.9 plants at the end of the fourth. These results indicate that the 2,4-D treatment was helpful in reducing the rate of reinfestation by leafy spurge.

Crop yields. In the first experiment, Mo-0-205 oats unsprayed, sprayed with $1 / 4 \mathrm{lb} / \mathrm{A}$ of 2,4-D amine, or with $1 / 3 \mathrm{lb} / \mathrm{A}$ of $2,4-\mathrm{D}$ ester, yielded $62.1,62.9$, and $62.3 \mathrm{bu} / \mathrm{A}$, respectively. In the second experiment, Garry oats produced 71.5, 73.3, 67.1, and 77.9 $\mathrm{bu} / \mathrm{A}$ on plots that were unsprayed, treated with $1 / 4 \mathrm{lb} / \mathrm{A}$ of $2,4-\mathrm{D}$ amine, $1 / 3 \mathrm{lb} / \mathrm{A}$ of 2,4$\mathrm{D}$ ester, or $1 \mathrm{lb} / \mathrm{A}$ of 4-(2,4-DB), respectively. Unsprayed Selkirk wheat yielded 23.9 and $16.8 \mathrm{bu} / \mathrm{A}$ in two experiments, while that sprayed with $1 / 2 \mathrm{lb} / \mathrm{A} 2,4-\mathrm{D}$ ester produced 19.5 and $16.4 \mathrm{bu} / \mathrm{A}$. S.D. 270 corn yielded 19.1 and $51.5 \mathrm{bu} / \mathrm{A}$ when unsprayed and 23.4 and 46.5 bushels when sprayed with $1 / 3 \mathrm{lb} / \mathrm{A}$ of 2,4-D ester in two experiments.

Summary. Seven treatments allowed reinfestation of more than 1 plant per square yard. Four of them did not include 2,4-D application any of the 4 years. Plots that received 2,4-D each of the 4 years contained 0.4 plants per square yard with a range of 0 to 1.9 plants. This statement can be repeated for plots receiving the 15 treatments that utilized 2,4-D the fourth year and included sprayed small grain, sprayed corn or a forage crop during previous years.

\section{Discussion}

Although the results from various combinations of cultivation, cropping and spraying are essentially the same as reported previously (15), this study shows that the various combinations can be incorporated into profitable crop rotations.

The authors' choice of treatments include treatments 5, 8, 15, 25, 29 and 32 in Table 1. Treatment 8 might have been improved by the use of 2,4-D in the corn crop. All treatments might have been improved by a post-tasseling application of 2,4-D in the corn with a high-clearance sprayer. Such treatment would apply constant pressure to the leafy 
spurge for a 4-year period. Although 2,4-D was used several times in each rotation, intensive cultivation, which appeared to be more effective, was used whenever possible. These treatments are less dependent on the effectiveness of an herbicide than other similar treatments. They should be more effective in eliminating a population containing strains that are resistant to the herbicide.

The variety of control methods can be increased by the use of 2,3,6-TBA or amitrole. The substitution of the first year of treatment 7 of Experiment 1 in Table 2 for the small grain year of any treatment in Table 1 should improve that treatment. Likewise the substitution of the first year of treatments 4, 7 or 13 of Experiment 2 in Table 2 for the fourth year of any treatment in Table 1 should improve that treatment. In areas where 2,3,6TBA injures corn, it may be advisable to use treatments 4 or 13 (Table 2) in preference to treatment 7. Treatment 8 (Table 1) did not leave the soil bare over winter. Treatment 5 and 15 left it bare over winter after the third year. Treatment 32 left it bare after the second and third years and treatment 29 left it bare over three winters. Therefore, soil erosion problems as well as crop utilization need to be considered when selecting the program to follow.

The authors believe that a cultivator with sharp 24- to 30-inch sweeps can be substituted for the plow and cultivator used in these treatments. This implement would aid in reducing the stand of weeds and leave a stubble mulch on the soil surface. If application of 2,3,6-TBA is substituted for fall cultivation after small grain harvest, it is doubtful if a wide-sweep cultivator could be substituted for the late summer plowing required for effective weed control with 4 to $6 \mathrm{lb} / \mathrm{A}$ of that herbicide.

\section{Conclusions}

1. Leafy spurge can be almost completely eliminated while utilizing crop sequences adapted to South Dakota without causing serious soil deterioration.

2. Leafy spurge stands can be materially reduced by several combinations of crops, cultivation and herbicides:(a) three cultivations, a close-drilled crop of sudangrass and fall cultivation, (b) a short season of intensive cultivation and an August seeding of Alfalfa or bromegrass, (c) spring application of 4 to $6 \mathrm{lb} / \mathrm{A}$ of 2,3,6-TBA or 6 to $8 \mathrm{lb} / \mathrm{A}$ of amitrole, plowing 10 days later, and a corn crop cultivated three times and sprayed with $1 / 3 \mathrm{lb} / \mathrm{A}$ of 2,4-D ester 1 week after first cultivation, or (d) a small grain crop sprayed with $1 / 3$ pound 2,4-D ester, and a postharvest application of 4 to $6 \mathrm{lb} / \mathrm{A}$ of 2,3,6-TBA, and plowing 10 days later.

3. Leafy spurge stands can be slightly reduced by: (a) spraying in bromegrass with 1 $\mathrm{lb} / \mathrm{A}$ of 2,4-D ester in June and again in mid-August, and (b) spraying in small grain with $1 / 3$ to $1 / 2 \mathrm{lb} / \mathrm{A}$ of $2,4-\mathrm{D}$ ester and cultivating three to four times after harvest.

4. Leafy spurge can be held in check by: (a) spraying in small grain or corn with 2,4D ester, (b) a good stand of alfalfa, (c) postharvest application of 2,3,6-TBA or amitrole after having used the same herbicide before planting corn the previous year.

Page 13 of 14 
5. These various combinations of cropping, cultivation and spraying can be incorporated into numerous 4-year programs that will eliminate leafy spurge if one of the combinations that materially reduces stands is used 1 or 2 years in the program.

6. Reinfestation by seedlings can be prevented while using soil building crop rotations. Legume crops (alfalfa or sweetclover) or the annual application of 2,4-D required to control annual broad-leaved weeds in small grain or corn will kill leafy spurge seedlings.

\section{Literature cited}

1. Arny, A. C. 1932. Variations in organic reserves in underground parts of five perennial weeds from late May to November. Minnesota Agr. Exp. Sta. Bul. 84.

2. Bakke, A. L. 1937. Control of leafy spurge, Euphorbia Esula L. Iowa Agr. Exp. Sta. Bul. 222.

3. Bakke, A. L. 1939. Experiments on the control of European bindweed. Iowa Agr. Exp. Sta. Bul. 259, pp. 367-440.

4. Bakke, A. L. Gaessler, W. G., and Loomis, W. E. 1939. Relation of root reserves to control of European bindweed Convolvulus arvensis L. Iowa Agr. Exp. Sta. Res. Bul. 254.

5. Bakke, A. L. Gaessler, W. G., Plutz, L. M., and Salmon, S. C. 1944. Relation of cultivation to depletion of root reserves in European bindweed at different soil horizons. Jour. Agr. Res. 69:137-47.

6. Craig, H. A. 1957. A leafy spurge eradication program. Proc. NCWCC 14:18-19.

7. Franzke, C. J., and Hume, A. N. 1936. Field bindweed and control methods for South Dakota. South Dakota Agr. Exp. Sta. Bul. 305.

8. Frazier, J. C. 1941 Advantages of a fourteen-day interval of cultivation for control of field bindweed. Am. Jour. Bot. 28:125.

9. Frazier, J. C. Nature and rate of development of root system of Convolvulus arvensis. Bot. Gaz. 104:41725. 1942.

10. Hanson, H. C., and Rudd, Velva E. 1933. Leafy spurge-life history and habits. North Dakota Agr. Exp. Sta. Bul. 266.

11. Stahler, L. M. 1948. Shade and moisture factors in competition between selected crops and field bindweed, Convolvulus arvensis. Jour. Am. Soc. Agron. 40:490.

12. Stevens, O. A. 1950. Handbook of North Dakota Plants. North Dakota Inst. for Regional Studies. Knight Printing Co. Fargo, N. Dak.

13. Timmons, F. L. 1941. Results of bindweed control experiments at the Fort Hays Branch Station. Kansas Agr. Exp. Sta. Bul. 296.

14. Timmons, F. L. and Bruns, V. F. 1951. Frequency and depth of shoot-cutting in eradication of certain creeping perennial weeds. Agron. Jour. 43:371-5.

15. Derscheid, Lyle A., Wallace, Keith E., and Nash, Russel L. 1960. Leafy spurge control with cultivation, cropping and chemicals. Weeds 8:115-27.

16. Derscheid, Lyle A., Wicks, Gail A., and Wallace, Wilford H. 1963. Cropping, cultivation and chemicals to prevent reinfestation of leafy spurge. Weeds 11:105-111.

17. Timmons, F. L., and Bruns, V. F. 1951. Frequency and depth of shoot-cutting in eradication of certain creeping perennial weeds. Agron. J. 43:371-5. 